\title{
CONCISE
}

PUBLICATIONS

\section{Calcium-Mobilizing Effect of Large Doses of 25-Hydroxycholecalciferol in Anephric Rats}

\author{
Henriette Pavlovitch, Michele Garabedian, and Sonia Balsan \\ From the Laboratoires des Tissus Calcifiés (Centre National de Recherche \\ Scientifique, équipe de recherche 126) et Unité de Recherches sur les \\ Maladies du Métabolism chez l'enfant (Institut National de Santé et de \\ Recherche Médicale, Unité de Recherche 30), Hôpital des Enfants Malades, \\ Paris, France
}

\begin{abstract}
A в S T R A C T The effect of high doses of 25-hydroxycholecalciferol on plasma calcium concentration was studied in rats receiving a low-calcium normal vitamin D diet. In bilaterally nephrectomized animals, as in shamoperated controls, $62.5 \mathrm{nmol}$ of 25 -hyroxycholecalciferol did not produce a rise of plasma calcium concentration. In contrast, the administration of 125 or $625 \mathrm{nmol}$, doses $1,000-5,000$ times the minimal active dose in D-deficient rats, was followed in both groups of animals by a significant increase of plasma calcium concentration. Removal of either parathyroids alone or parathyroid and thyroid glands did not suppress this effect. These data suggest that when large doses are used in vivo, the renal conversion of 25-hydroxycholecalciferol to more polar metabolites is not an obligatory step for its calciummobilizing action. The present study does not elucidate, however, the exact mechanism(s) of this effect.
\end{abstract}

\section{INTRODUCTION}

25-hydroxycholecalciferol $\left(25-(\mathrm{OH})-\mathrm{D}_{3}\right)^{1}$ was isolated, identified, and synthesized by Lund and DeLuca, Blunt, DeLuca, and Schnoes, and DeLùca (1-3). More recently it has been demonstrated that this metabolite, the major

Received for publication 17 April 1973 and in revised form 6 July 1973.

${ }^{1}$ Abbreviations used in this paper: $25-(\mathrm{OH})-\mathrm{D}_{3}, 25-\mathrm{hy}-$ droxycholecalciferol ; $1,25-(\mathrm{OH})_{2}-\mathrm{D}_{3}, 1,25$-dihydroxycholecalciferol ; PTX, parathyroidectomized; TPTX, thyroparathyroidectomized. circulating form of vitamin $\mathrm{D}$, becomes biologically active only if converted to more polar substances (4-7). The currently available in vivo data indicate that the kidney is the only organ able to convert $25-(\mathrm{OH})-\mathrm{D}_{3}$ to 1,25-dihydroxycholecalciferol $\left(1,25-(\mathrm{OH})_{2}-\mathrm{D}_{8}\right), 24,25$ dihydroxycholecalciferol, and other metabolites (8-10). Furthermore it is well established that as much as 62.5 nmol of $25-(\mathrm{OH})-\mathrm{D}_{3}$ will not produce the characteristic bone calcium mobilization effect in D-deficient rats if the kidneys ars removed $(11,12)$. Yet in vitro organ culture studies (13-14) and our clinical results (15) are not in complete agreement with these conclusions. In fact, a calcium-mobilizing effect of $25-(\mathrm{OH})-\mathrm{D}_{3}$ has been observed in bone tissue cultures when high concentrations of $25-(\mathrm{OH})-\mathrm{D}_{3}$ were added to the medium (13-14); and we have seen that large doses of $25-(\mathrm{OH})-\mathrm{D}_{3}$ are highly active on bones of severely uremic children with glomerular filtration rates less than $10 \mathrm{ml} / \mathrm{min} / 1.73 \mathrm{~m}^{2}$ (15). The apparent contradiction between the in vitro data, the clinical observations, and the experimental results in laboratory animals may be explained in different ways: (a) conditions of in vitro and in vivo studies may not be comparable; $(b)$ the small amount of functioning renal tissue in our patients may have been sufficient to permit conversion of $25-(\mathrm{OH})-\mathrm{D}_{\mathbf{3}}$ to more polar active metabolite (s); (c) pharmacological doses of $25-(\mathrm{OH})-\mathrm{D}_{\mathbf{z}}$, by some mechanism(s) yet to be defined, may be active even in the absence of kidneys. The present study was undertaken to investigate the third hypothesis, that of 
the possible calcium-mobilizing effect of large doses of $25-(\mathrm{OH})-\mathrm{D}_{3}$ in anephric animals. In order to test whether this action of $25-(\mathrm{OH})-\mathrm{D}_{3}$ is parathyroid- or thyroid-dependent, the experimental procedure was done in the presence and the absence of these glands.

\section{METHODS}

25- $(O H)-D_{s}$. Crystalline $25-(\mathrm{OH})-\mathrm{D}_{3}$ used in this study was a gift from Roussel Laboratories, Paris, France. It was synthesized according to the Blunt and DeLuca technique (16). A possible contamination of $25-(\mathrm{OH})-\mathrm{D}_{3}$ with 5,6-trans-25- $(\mathrm{OH})-\mathrm{D}_{\mathbf{3}}$ was checked by gas liquid chromatography performed on a Erba Science Model $2400 \mathrm{~T}$, with a $4 \mathrm{ft} \times 0.25$ in glass column packed with $3 \% \mathrm{SE} 30$ on gas-Chrom Z 100-200 mesh (Erba Science, Paris, France). The column temperature was $255^{\circ} \mathrm{C}$, and an outlet flow rate of $40 \mathrm{~cm} / \mathrm{min}$ was maintained. The contaminant in our batch of $25-(\mathrm{OH})-\mathrm{D}_{3}$ was found to be $1.2 \%$.

Experimental animals and protocol. Weanling 21-day-old male albino Wistar rats were used for all experiments (Sodelabo, Conde s/Huisne, France). They were given food and deionised drinking water ad libitum. The synthetic diet (17) containing $0.47 \%$ calcium and $30 \%$ phosphorus was supplemented daily with adequate amounts of fat-soluble vitamins. After 5 days on this diet animals were randomly divided into three groups. Rats from the first group had their parathyroids destroyed by hot-wire cautery (PTX), those from the second group were surgically thyroparathyroidectomized (TPTX), and the animals of the third group, sham-operated, had their tracheas exposed. After surgery the animals were fed a low-calcium diet (18) containing $0.02 \%$ calcium and $0.30 \%$ phosphorus for 3 days. At this time plasma calcium concentration was determined in samples obtained by tail incision. In control animals it was $9.1 \pm 0.2 \mathrm{mg} / 100 \mathrm{ml}$. In the group of PTX and TPTX animals only those with a plasma calcium concentration less than $6 \mathrm{mg} / 100 \mathrm{ml}$ were considered successfully operated and used in the study. Then, in sham-operated and PTX groups, half the animals were bilaterally nephrectomized, and the others had exploration of the renal area. Immediately after nephrectomy or sham operation, the solvent alone $(0.05 \mathrm{ml}$ of $95 \%$ ethanol) or different doses of 25 $(\mathrm{OH})-\mathrm{D}_{3}$, i.e., $62.5,125$, or $625 \mathrm{nmol}$, was administered intrajugularly. $24 \mathrm{~h}$ later the animals were killed by decapitation, and the blood was collected in heparin tubes. All surgical procedures were carried out under ether anesthesia. Plasma calcium concentration was determined on each sample separately with a titrator (Marius Calcium Titrator, Amsterdam, Netherlands). Student's $t$ test was used for statistical analysis of results (19).

\section{RESULTS}

The plasma calcium concentrations (mean tone SD) observed in different experimental groups $24 \mathrm{~h}$ after administration of the various doses of $25-(\mathrm{OH})-\mathrm{D}_{3}$ are summarized in Table I.

Nonnephrectomized rats. This group of animals includes rats with intact thyroid and parathyroid glands, and PTX and TPTX ones. The pretreatment levels of plasma calcium were respectively, 9.3 $\pm 0.1,9.3 \pm 0.1$, $8.9 \pm 0.2$, and $9.1 \pm 0.1 \mathrm{mg} / 100 \mathrm{ml}$ in sham-operated rats; $5.4 \pm 0.1,5.4 \pm 0.1,4.8 \pm 0.1$, and $5.1 \pm 0.2 \mathrm{mg} / 100 \mathrm{ml}$ in PTX rats, and $5.6 \pm 0.1,5.7 \pm 0.1,5.5 \pm 0.1$, and $5.7 \pm 0.2 \mathrm{mg} / 100$ $\mathrm{ml}$ in TPTX rats. No significant changes of plasma calcium concentrations were observed in any of these subgroups $24 \mathrm{~h}$ after intrajugular injection of $62.5 \mathrm{nmol}$ of $25-(\mathrm{OH})-\mathrm{D}_{3}$. In contrast, the administration of $125 \mathrm{nmol}$ of $25-(\mathrm{OH})-\mathrm{D}_{3}$ was followed in sham-operated, PTX, and TPTX rats by a significant rise of plasma calcium concentration. Increasing the dose of $25-(\mathrm{OH})-\mathrm{D}_{3}$ to $625 \mathrm{nmol}$ provokes a slight but significant $(P<0.02)$ enhancement of this response. In PTX and TPTX rats the rise of plasma calcium concentration is also more important after administration of $625 \mathrm{nmol}$ when com-

TABLE I

Calcium-Mobilizing Effect of 25-(OH)- $\mathrm{D}_{3}$

\begin{tabular}{|c|c|c|c|c|c|}
\hline \multirow[b]{3}{*}{ Dose of $25-(\mathrm{OH})-\mathrm{D}_{3}$} & \multicolumn{5}{|c|}{ Plasma calcium concentration } \\
\hline & \multicolumn{3}{|c|}{ Unnephrectomized rats } & \multicolumn{2}{|c|}{ Nephrectomized rats } \\
\hline & Non-PTX & PTX & TPTX & Non-PTX & PTX \\
\hline & \multicolumn{5}{|c|}{$m g / 100 \mathrm{ml}$} \\
\hline none & $\begin{array}{c}9.4 \pm 0.1 \\
\quad(7)\end{array}$ & $\begin{array}{c}5.2 \pm 0.2 \\
\quad(12)\end{array}$ & $\begin{array}{l}5.3 \pm 0.1 \\
(6)\end{array}$ & $\begin{array}{c}10.4 \pm 0.2 \\
(10)\end{array}$ & $\begin{array}{c}5.5 \pm 0.4 \\
(6)\end{array}$ \\
\hline $62.5 \mathrm{nmol}$ & $\begin{array}{c}9.3 \pm 0.2 \\
(6)\end{array}$ & $\begin{array}{c}5.7 \pm 0.4 \\
(8)\end{array}$ & $\begin{array}{c}5.6 \pm 0.2 \\
(8)\end{array}$ & $\begin{array}{c}10.2 \pm 0.2 \\
(7)\end{array}$ & $\begin{array}{c}5.7 \pm 0.3 \\
(10)\end{array}$ \\
\hline $125 \mathrm{nmol}$ & $\begin{array}{c}10.2 \pm 0.1 \\
(9)\end{array}$ & $\begin{array}{c}7.1 \pm 0.4 \\
(9)\end{array}$ & $\begin{array}{c}7.5 \pm 0.2 \\
(8)\end{array}$ & $\begin{array}{c}13.6 \pm 0.4 \\
\quad(13)\end{array}$ & $\begin{array}{c}7.4 \pm 0.4 \\
(8)\end{array}$ \\
\hline & $P<0.001$ & $P<0.001$ & $P<0.001$ & $P<0.001$ & $P<0.001$ \\
\hline $625 \mathrm{nmol}$ & $\begin{array}{c}10.8 \pm 0.2 \\
(7)\end{array}$ & $\begin{array}{c}8.6 \pm 0.3 \\
\quad(11)\end{array}$ & $\begin{array}{c}9.2 \pm 0.3 \\
(8)\end{array}$ & $\begin{array}{c}15.8 \pm 0.5 \\
(13)\end{array}$ & $\begin{array}{c}9.1 \pm 0.5 \\
(9)\end{array}$ \\
\hline & $P<0.001$ & $P<0.001$ & $P<0.001$ & $P<0.001$ & $P<0.001$ \\
\hline
\end{tabular}

All values are mean $\pm \mathrm{SD}, P$ values are those comparing a treatment with the appropriate control (no treatment) in each group, and numbers in brackets indicate the number of animals. 
pared with that provoked by $125 \mathrm{nmol}(P<0.001$ for PTX rats and $P<0.01$ for TPTX ones). Thus, the calcium-mobilizing effect of $25-(\mathrm{OH})-\mathrm{D}_{\mathbf{3}}$ in rats with an adequate supply of vitamin $D$ appears only when the doses used are at least 1,000 times that shown to be active in $\mathrm{D}$-deficient animals, i.e. $125 \mathrm{nmol}$ vs. 0.125 nmol $(12,20)$.

Anephric rats. Anong the nephrectomized animals, some had been previously parathyroidectomized and others had had their trachea exposed.

The plasma calcium level before nephrectomy was $8.9 \pm 0.2,9.3 \pm 0.4,8.9 \pm 0.2$, and $9.3 \pm 0.3 \mathrm{mg} / 100 \mathrm{ml}$ in non-PTX animals, and $5.1 \pm 0.2,5.2 \pm 0.1,5.3 \pm 0.2$, and $4.9 \pm 0.2$ in PTX ones. In the non-PTX rats, $24 \mathrm{~h}$ after kidney ablation a significant rise of plasma calcium concentration $(P<0.001)$ is observed in untreated animals. This hypercalcemic effect of bilateral nephrectomy, already reported by Jastak, Morrison, and Raisz (21) and Delorme, Cuisinier-Gleizes, Dulac, and Mathieu (22) in non-vitamin D-deficient rats, is generally attributed to increased secretion of parathyroid hormone after kidney ablation. In fact, this rise of plasma calcium is abolished in previously PTX rats. In nephrectomized animals, as in nonnephrectomized ones, changes of plasma calcium concentration observed after intrajugular injection of $62.5 \mathrm{nmol}$ of $25-(\mathrm{OH})-\mathrm{D}_{3}$ are not different from those observed in untreated animals. But 125 nmol produces a significant rise of serum calcium concentration $(P<$ 0.001 in both non-PTX and PTX animals); this response is also significantly $(P<0.01)$ more pronounced after administration of $625 \mathrm{nmol}$ of $25-(\mathrm{OH})-\mathrm{D}_{\mathbf{s}}$. Thus, in nephrectomized, as in unnephrectomized rats, the presence or the absence of the parathyroid glands does not significantly change the calcium-mobilizing action of the different doses of 25-(OH)-Ds.

\section{DISCUSSION}

New developments in the understanding of the mechanism of action of vitamin $\mathrm{D}$ and its active metabolites have led to the synthesis of 5,6-trans isomers (23). Furthermore, these compounds have been shown to be active on intestinal absorption and bone mobilization of calcium in anephric animals. Before any interpretation of our results is made, it seems essential to discuss whether any of the changes observed could possibly be due to the contaminant $(\mathrm{s})$ in the batch of $25-(\mathrm{OH})-\mathrm{D}_{\mathbf{z}}$ used. The proportion of contaminants of the $25-(\mathrm{OH})-\mathrm{D}_{3}$ we utilized in these experiments was found to be $1.2 \%$. Even with the larger dose administered to the animals, i.e. 625 nmol, this would represent at most $7.5 \mathrm{nmol}$ of 5,6-trans25- $(\mathrm{OH})-\mathrm{Ds}$. It has been demonstrated that the minimal active dose of this isomer in anephric animals is 62.5 nmol (23). Hence, we may reasonably assume that the observed changes in serum calcium concentrations are the consequence of the intrajugular injection of 25 $(\mathrm{OH})-\mathrm{D}_{\mathbf{8}}$ itself.

The data indicate clearly, that very large doses of 25$(\mathrm{OH})-\mathrm{D}_{3}$ promotes a rapid increase of plasma calcium concentration in nephrectomized animals receiving a low calcium diet. In this experimental condition acute changes of plasma calcium are most probably due to release of calcium from body stores. It should be emphasized that this calcium-mobilizing effect of $25-(\mathrm{OH})-\mathrm{D}_{\text {: }}$ is observed at a dose level equal to or greater than $125 \mathrm{nmol}$, that is, a dose at least 1,000 times the minimal active level in the D-deficient rat $(12,20)$. The present results also show that this action is not parathyroid- or thyroid-dependent, since it is not suppressed by removal of these glands. Moreover it indicates that this action is not modified by the basic level of plasma calcium concentration, as it occurs in sham-operated animals with a plasma calcium of $9.0 \pm 0.1$, and in PTX or TPTX animals with a plasma calcium concentration, respectively, of 5.1 \pm 0.1 and $5.6 \pm 0.1$. Yet the importance of these parameters for the further metabolism of $25-(\mathrm{OH})-\mathrm{D}_{3}$, though contested by Shain (24), has been suggested by several in vivo and in vitro experiments (25-29).

Although the present study does not elucidate the exact mechanism (s) by which high doses of 25-(OH)-D: are active in anephric animals, it does show conclusively that: (a) renal conversion of this metabolite is not an obligatory step in the calcium-mobilizing action of such doses; and $(b)$ this biological activity, either a direct effect of 25- $(\mathrm{OH})-\mathrm{D}_{3}$ itself or a secondary effect of the extrarenal formation of a presently unidentified metabolite, does not require the presence of the parathyroid or thyroid gland and is not modified by extracellular concentration of calcium.

\section{REFERENCES}

1. Lund, J., and H. F. DeLuca. 1966. Biologically active metabolite of vitamin $D_{3}$ from bone, liver, and blood serum. J. Lipid. Res. 7 : 739.

2. Blunt, J. W., H. F. DeLuca, and H. K. Schnoes. 1968. 25-hydroxycholecalciferol. A biologically active metabolite of vitamin $\mathrm{D}_{3}$. Biochemistry. $7: 3317$.

3. DeLuca, H. F. 1969. 25-hydroxycholecalciferol, the probable metabolically active form of vitamin $D$. $\mathrm{Am}$. J. Clin. Nutr. $22: 412$.

4. Lawson, D. E. M., D. B. Fraser, E. Kodicek, H. R. Morris, and D. H. Williams. 1971. Identification of 1,25 dihydroxycholecalciferol a new kidney hormone controlling calcium metabolism. Nature (Lond.). 230: 228.

5. Holick, M. F., H. K. Schnoes, H. F. DeLuca, T. Suda, and P. S. Cousins. 1971. Isolation and identification of 1,25-dihydroxycholecalciferol. A metabolite of vitamin $D$ active in intestine. Biochemistry. 10: 2799. 
6. Myrtle, J. F., and A. W. Norman. 1971. Vitamin D: a cholecalciferol metabolite highly active in promoting intestinal calcium transport. Science (Wash. D. C.). 17.1: 79.

7. Haussler, M. R., D. W. Boyce, E. T. Littledike, and H. Rasmussen. 1971. A rapidly acting metabolite of vitamin Ds. Proc. Natl. Acad. Sci. U. S. A. 68: 177.

8. Fraser, D. R., and E. Kodicek. 1970. Unique biosynthesis by kidney of a biologically active vitamin D metabolite. Nature (Lond.). 228: 764.

9. Gray, R., I. Boyle, and H. F. DeLuca. 1971. Vitamin D metabolism. Role of kidney tissue. Science (Wash. D. C.). 172: 1232.

10. Holick, M. F., H. K. Schnoes, H. F. DeLuca, R. W. Gray, I. T. Boyle, and T. Suda. 1972. Isolation and identification of 24,25-dihydroxycholecalciferol, a metabolite of vitamin $\mathrm{D}_{8}$ made in the kidney. Biochemistry. $11: 4251$.

11. Holick, M. F., M. Garabedian, and H. F. DeLuca. 1972. 1,25-dihydroxycholecalciferol: metabolite of vitamin $D_{s}$ active on bone in anephric rats. Science (Wash. D. C.). $176: 1146$.

12. Wong, R. G., A. W. Norman, Ch. R. Reddy, and J. W. Coburn. 1972. Biologic effects of 1,25-dihydroxycholecalciferol (a highly active vitamin D metabolite) in acutely uremic rats. J. Clin. Invest. 51: 1287.

13. Trummel, C. L., L. G. Raisz, J. W. Blunt, and H. F. DeLuca. 1969. 25-hydroxycholecalciferol stimulation of bone resorption in tissue culture. Science (Wash. D.C.). 163: 1450

14. Reynolds, J. J. 1972. Effect of vitamin $D_{z}$ and its metabolites in bone in vitro. Ninth european symposium on calcified tissues. H. Egermann, editor. Verlag der Wiener Medizinischen Akademie, Vienna. 454.

15. Balsan, S., and G. Witmer. 1971. Treatment of renal osteodystrophy with 25-hydroxycholecalciferol. Second International Symposium of Pediatric Nephrology. Laboratoires Sandoz, Rueil-Malmaison, France. 108.

16. Blunt, J. W., and H. F. DeLuca. 1969. The synthesis of 25-hydroxycholecalciferol. A biologically active metabolite of vitamin $D_{8}$. Biochemistry. 8: 671 .

17. Guroff, G., H. F. DeLuca, and H. Steenbock. 1963. Citrate and action of vitamin D on calcium and phosphorus metabolism. Am. J. Physiol. 204: 833.
18. Suda, T., H. F. DeLuca, and Y. Tanaka. 1970. Biological activity of 25-hydroxy-ergocalciferol in rats. $J$. Nutr. 100: 1049.

19. Schwartz, D. 1963. Méthodes statistiques à l'usage des Médecins et Biologistes. Flammarion et Cie, Paris. 3d edition. 157.

20. Wong, R. G., J. F. Myrtle, H. C. Tsai, and A. W. Norman. 1972. Studies on calciferol metabolism. V. The occurrence and biological activity of 1,25-dihydroxyvitamin $\mathrm{D}_{8}$ in bone. J. Biol. Chem. 247: 5728.

21. Jastak, J. T., A. B. Morrison, and L. G. Raisz. 1968. Effects of renal insufficiency on the parathyroid gland and calcium homeostasis. Am. J. Physiol. 215: 84 .

22. Delorme, A., P. Cuisinier-Gleizes, H. Dulac, and $H$. Mathieu. 1972. Rôle du rein dans l'action osteolytique du 25-hydroxycholécalciférol. C.R. Hebd. Séances Acad. Sci. Ser. D. Sci. Nat. (Paris). 275: 1091.

23. Holick, M. F., M. Garabedian, and H. F. DeLuca. 1972. 5,6-trans isomers of cholecalciferol and 25-hydroxycholecalciferol. Substitutes for 1,25-dihydroxycholecalciferol in anephric animals. Biochemistry. 11: 2715.

24. Shain, S. A. 1972. The in vitro metabolism of 25-hydroxycholecalciferol to 1,25-dihydroxycholecalciferol by chick renal tubules. Effect of actomycin D, puromycin, calcium, and parathyroid hormone. J. Biol. Chem. 247: 4404.

25. Boyle, I. T., R. W. Gray, and H. F. DeLuca. 1971. Regulation by calcum of in vivo synthesis of 1,25dihydroxycholecalciferol and 21,25-dihydroxycholecalciferol. Proc. Natl. Acad. Sci. U. S. A. 68: 2131.

26. Galante, L., S. MacAuley, K. Colston, and I. MacIntyre. 1972. Effect of parathyroid extract on vitamin D metabolism. Lancet. 1: 985.

27. Galante, L., K. W Colston, S. J. MacAuley, and I. MacIntyre. 1972. Effect of calcitonin on vitamin-D metabolism. Nature (Lond.). 238: 271.

28. Garabedian, M., M. F. Holick, H. F. DeLuca, and I. T. Boyle. 1972. Control of 25-hydroxycholecalciferol metabolism by parathyroid glands. Proc. Natl. Acad. Sci. U.S. A. $69: 1673$.

29. Rasmussen, H., M. Wong, D. Bikle, and D. B. P. Goodman. 1972. Hormonal control of the renal conversion of 25-hydroxycholecalciferol to 1,25-dihydroxycholecalciferol. J. Clin. Invest. 51: 2502. 